\title{
Microbiological and Ecophysiological Characterization of Green Algae Dunaliella sp. for Improvement of Carotenoid Production
}

\author{
Muhammad Zainuri 1), Hermin P. Kusumaningrum ${ }^{2)}$, Endang Kusdiyantini ${ }^{2)}$ \\ 1) Laboratory of Biological Oceanography Laboratory, Department of Marine Sciences, \\ Faculty of Fisheries and Marine Sciences, Diponegoro University \\ e-mail:muhammad.zainuri@yahoo.co.id \\ 2) Microbiogenetics Laboratory, Faculty of Mathematics and Natural Sciences, Diponegoro University \\ JI. Prof. Soedarto, UNDIP, Tembalang, Semarang. 50275.
}

Diterima 08-01-2008 Disetujui 25-03-2008

\begin{abstract}
An isolate of green algae Dunaliella sp. from BBAP Jepara is usually used as a source for carotenoid supplement for marine animal cultivation in the local area. In order to improve carotenoid production especially detection of biosynthetic pathway from the organisms investigated in this study, the main purpose of this study is characterizing Dunaliella sp. based on it's microbiological and ecophysiological characters. The research was done by characterize the growth, the cell and colonies microbiologically, total pigment production, and also characterize all of the ecophysiological factors affecting the algal growth and survival. The results of this research showed that Dunaliella sp. posseses typical characteristic of green eucaryote alga, in their growth and ecological condition. The extreme characters which was toleration ability to high salinity environment of was used to conclude Dunaliella sp. as Dunaliella salina.
\end{abstract}

Keywords: algae, characterization, Dunaliella sp., eco-physiological, microbiological.

\section{INTRODUCTION}

Green algae are simple photosynthetic eukaryotes which are responsible for up to $50 \%$ of the planet's atmospheric carbon fixation. The recent discoveries of health related beneficial properties attributed to algal carotenoids have spurred great interest in their production. Carotenoids, some of which are provitamin A, have range of diverse biological function and actions, such as species specific coloration, photo protection, and light harvesting, and they serve as precursors of many hormones (Vershinin 1999 in Lee \& SchmidtDannert 2002). Carotenoids are used commercially as food colorants, animal feed supplements, and more recently, as nutraceuticals for cosmetic and pharmaceutical purposes. The demand and market for carotenoids are anticipated to change drastically with the discovery that carotenoids exhibit significant anticarcinogenic activity and play an important role in the prevention of chronic diseases (Lee \& Schmidt-Dannert 2002).

For many years, it was accepted that carotenoid was synthesized through the well known acetate/ mevalonate pathway. However, recent studies have demonstrated photosynthetic organisms including green algae, such as Scenedesmus obliquus, Chlorella fusca, Chlamydomonas reinhardii use a new non- mevalonate pathway known as deoxyxylulose 5phosphate (DXP) pathway for their carotenoid biosynthesis. The exclusive occurrence of the non-MVA pathway for the biosynthesis of plastidic isoprenoids and of sterols might represent a general feature of many green algae (Lois et al, 1998; Lichtenthaler 1999).

A local isolate of an algal species from BBPAP Jepara, called Dunaliella sp., was found potentially useful as source of carotenoids in food additives or as food supplement in fish farming. Thus, it was of great interest to know if this local isolate of algae would also follow the non-MVA pathway for carotenoid biosynthesis. This indigenous algae has been successfully cultivated. Therefore, it is important to examine species identification based on eco-physiological and morphological characteristics microbiologically, needed to support improvement of their carotenoid production.

\section{MATERIAL AND METHODS}

Culture Media. The Walne medium was used for culturing Dunaliella sp. modified from Bidwell \& Spotte (1983). The medium consist of EDTA $45 \mathrm{~g} / \mathrm{l}, \mathrm{FeCl}_{3} \cdot 6 \mathrm{H}_{2} \mathrm{O}$ $1.3 \mathrm{mg} / \mathrm{l}, \mathrm{H}_{3} \mathrm{BO}_{3} 33.6 \mathrm{~g} / \mathrm{l}, \mathrm{MnCl}_{2} \cdot 4 \mathrm{H}_{2} \mathrm{O} 0.36 \mathrm{~g} / \mathrm{l}, \mathrm{NH}_{4} \mathrm{NO}_{3}$ $100 \mathrm{~g} / \mathrm{l}, \mathrm{Na}_{2} \mathrm{PO}_{4} 20 \mathrm{~g} / \mathrm{l}, \mathrm{B}_{12}$ vitamin $0.001 \mathrm{ppm}$, distilled water until $1 \mathrm{I}$. Sterilization was done by autoclaving at $15 \mathrm{lb} / \mathrm{in}^{2}\left(103 \mathrm{kPa}\right.$ and $\left.120^{\circ} \mathrm{C}\right)$. The medium was using 
by adding $0.5 \mathrm{ml}$ solution to each $1 \mathrm{I}$ of seawater. For induction of $\beta$-carotene synthesis, cells were grown in a sulfate-depleted media $\left(\mathrm{MgCl}_{2}\right.$ instead of $\left.\mathrm{MgSO}_{4}\right)$, under intense illumination conditions $600 \mathrm{lux}$ and with 2-4 ppm $\mathrm{O}_{2}$ passing to the liquid (Rabbani et al, 1998).

Microbiological and eco-physiological Characterization. Microbiological characterization was done according to Sze, (1993), and Tomas, (1997). Microbiological characters include cell reproduction shape, curvature, size and arrangements. Pleomorphisms, formation of daughter cell, cell division and reproduction, presence and arrangement of flagel gliding motility, presence or lack of cell walls, presence or lack of nucleus walls, presence or lack of cell sheath.

Eco-physiological characterization was conducted according to Borowitzka \& Borowitzka, (1988), and BenAmotz, (1993), consist of the maximum and minimum temperatures permitting sustained growth, reproducibility, temperature tolerance, atmospheric requirements such as aeration and illumination, also salinity. Growth experiment was measured by cell count and cell density absorbencies at $\mathrm{OD}_{600 \mathrm{~nm}}$. Illumination was observed at 660 Einstein. $^{\text {m-2.sec-1 }}$ or 600 lux (Rabbani et al. 1998). Measurement of pigments concentration was done by extracting the specimen with methanol or acetone to check if residual color (blue to red) caused by the non-organic soluble phycobillins remains in the cell (Goodwin \& Britton 1988; Holt et al. 1994). Chlorophyll concentration was analyzed by extracting cell pellet with methanol until the pellet color is disappeared. Concentration of chlorophyll was measured by $\mathrm{OD}_{663 \mathrm{~nm}}$ and $\mathrm{OD}_{645 \mathrm{~nm}}$, then calculated with formulas (Harborne 1984; Goodwin \& Britton 1988):

Total chlorophyll $=17.3 \mathrm{~A}_{645}+7.18 \mathrm{~A}_{663} \mathrm{mg} / \mathrm{ml}$ chlorophyll a $=12.21 \mathrm{~A}_{663}-2.81 \mathrm{~A}_{645} \mathrm{mg} / \mathrm{ml}$ chlorophyll b $=20.13 \mathrm{~A}_{645}-5.03 \mathrm{~A}_{663} \mathrm{mg} / \mathrm{ml}$

\section{RESULTS AND DISCUSSION \\ Microbiological and Morphological} characterization. According to microscopic view as illustrated in Fig. 1, morphological characteristics of Dunaliella sp. is free-living organisms, unicellular and solitaire. Each cell has an ovoid space and is surrounded by a delicate wall. The flagella are smooth. A single large chloroplast in the shape of thick cup fills much of the volume of the cell. Cell was spherical or elongate in shape, widely oval before division and after division hemispherical. Cells of Dunaliella sp. swim actively by means of two anterior flagella is non motile cells and do not have flagella. The color of the cell is bright green and turn to greenish yellow on the sixth day of growth. Cells are surrounded by narrow, fine, green color envelopes. Cellular reproduction is by division into two morphologically equal, hemispherical daughter cells (binary fission), which reach the original globular shape before next division. Cells divide in one plane in successive generations in broth media (Fig. 2). The envelopes around cells will split together with dividing cells. Daughter cells separate after division and grow into the original size and shape before next binary fission. Daughter cells held together by mucilaginous sheath. Reproduction of cell was sexual or asexually (Fig. 3 and Fig. 4).

\section{Ecophysiological characterization.}

Ecophysiological characterization of Dunaliella sp. was carried out by growth and factor influencing growth including temperature, salinity and light. The comparison characteristic between these two organisms are presented in Table 1.

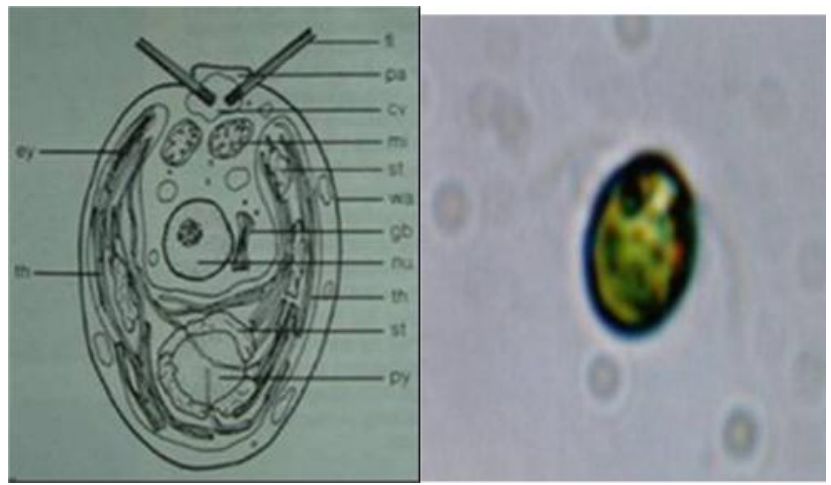

Figure 1. Microscopic View of a Dunaliella sp. ( $\mathrm{cv}=$ contractile vacuole, ey = eyespot, $\mathrm{fl}=$ flagellum, $\mathrm{gb}=$ Golgi body $\mathrm{mi}=$ mitochondria, $\mathrm{nu}=$ cell nucleus, $\mathrm{pa}=$ papillae, $\mathrm{py}=$ pyrenoid, st $=$ starch grain, th $=$ thylakoid, wa $=$ wall) (Sze, 1989)

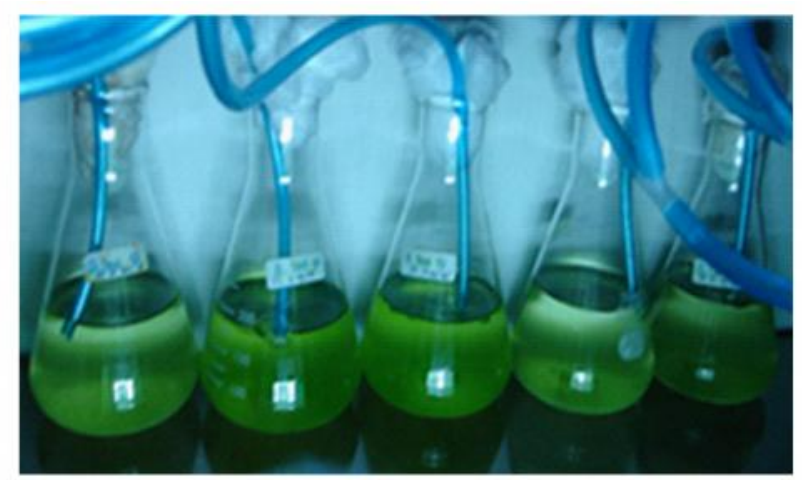

Figure 2. Cultures of Dunaliella sp. 


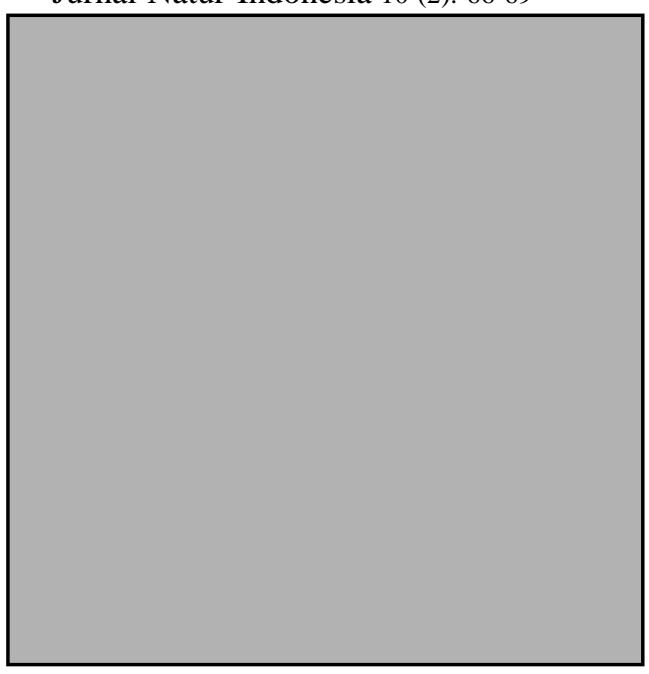

Figure 3. Sexual reproduction of Dunaliella sp.

Growth of Dunaliella sp. Dunaliella sp. appeared yellow-green after less than one week of growth (Fig. 5). It has been observed, that Dunaliella osmoregulates by varying the intracellular concentration of the photosynthetic glycerol in response to the extra cellular osmotic pressure. On growth in media containing different salt concentration, the intracellular glycerol concentration is directly proportional to the extra cellular salt concentration and maintains the cell water volume and the required cellular osmotic pressure (Kusumaningrum et al. 2004; 2006).

Table 1. Microbiological and ecophysiological characteristics of Dunaliella sp. (Hott et al, 1994)

\section{Characteristic Dunaliella sp.}

1. Cellular organization
2. Growth temperature
3. salinity
4. source of energy and carbon
5. habitat
6. unicellular
7. coccoid or spherical
8. binary fission in 2 succesive
planes
9. Extracelllular sheath
10. Chlorophyll a
11. Chlorophyll b
12. \%GC
13. filament
14. thylakoid
15. cell diameter
16. motility/movement
17. Cell
18. Colonies
19. Cell color
20. Color of sheath
21. Cell division
22. Reproduction

procaryotic $25^{\circ} \mathrm{C}-30{ }^{\circ} \mathrm{C}$ $25-40 \%$ Photoheterotroph, photoautotroph Sea Waters $+$ $+$ $+$ $+$ $+$ 58.7

-
+
$5-6 \quad \mathrm{~m}$
slow gliding
solitary
Forming colonies Bright green bright Binary fission solitary cells
Asexual Reproduction of Dunaliella sp.

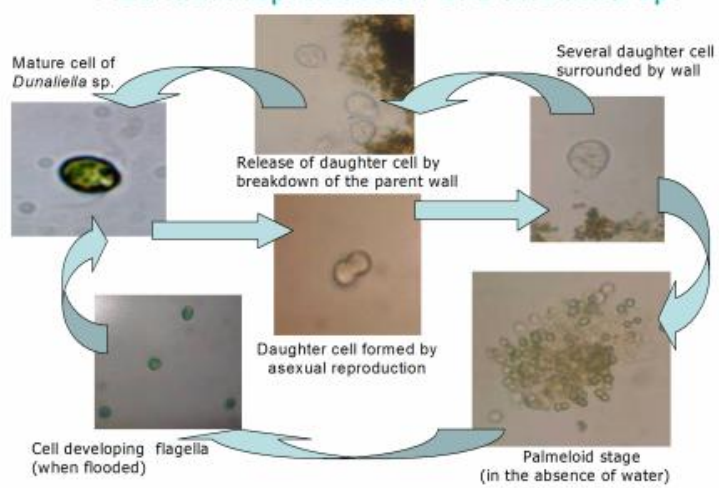

Figure 4. Asexual reproduction of Dunaliella sp.

The research result shows toleration ability of Dunaliella sp. on high salt concentration, as may occur in tide pools and lakes when evaporation concentrates salts (Sze 1993). Some studies also display that green algae Dunaliella showing a remarkable adaptation to a variety of salt concentration from as low as $0,2 \%$ to salt saturation of about $35 \%$ (Borowitzka \& Borowitzka 1988; Ben-Amotz 1993).

Some green algae will change their cell colors after several days under salinity $0,5-2,0 \mathrm{M}$ (Wong et al, 2000). It has been observed that Dunaliella

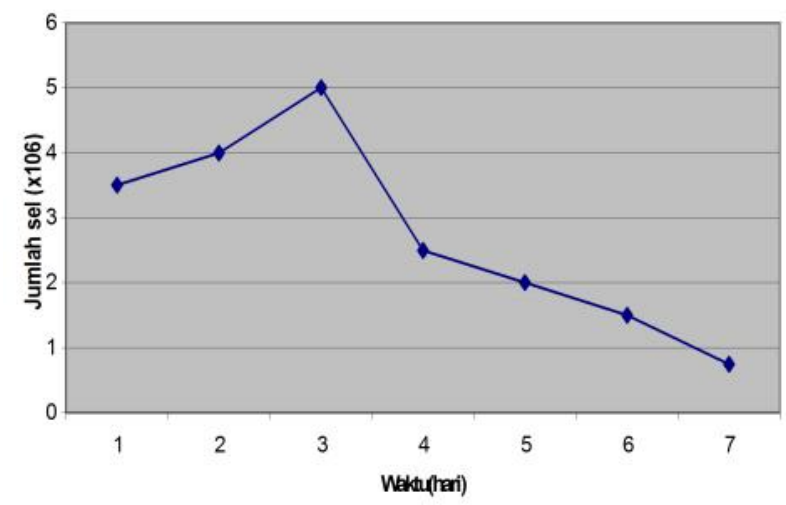

Figure 5. Growth curve of Dunaliella sp. on walne medium

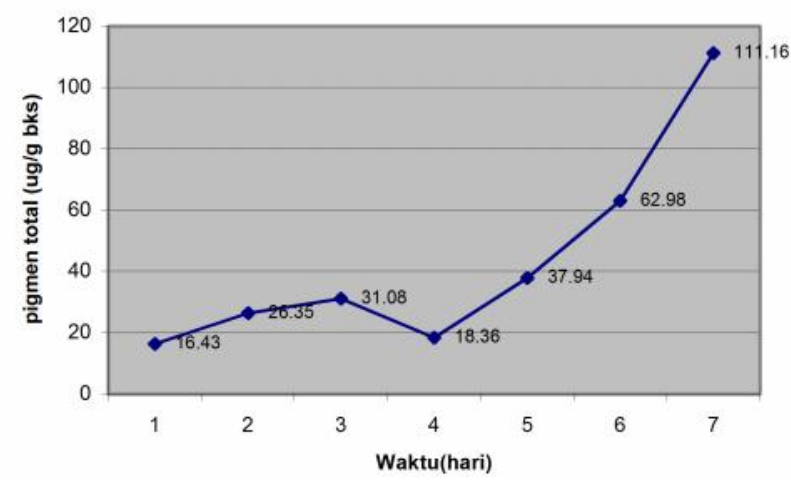

Figure 6. Total pigment production of Dunaliella sp. 
osmoregulates by varying the intracellular concentration of the photosynthetic glycerol in respons to the extra cellular osmotic pressure. On growth in media containing different salt concentration, the intracellular glycerol concentration is directly proportional to the extra cellular salt concentration and maintains the cell water volume and the required cellular osmotic pressure.

Pigment Production. Analysis of total pigment production on Dunaliella sp. exhibit an increase pigment production as illustrated in Fig. 6. Highest total pigment production reaches $111,16 \mathrm{~g} / \mathrm{g}$ bks or equivalent to 3,3-15,56 g/g bks $\beta$-karoten.

\section{CONCLUSION}

Characterization of Dunaliella sp. based on ecophysiological, microbiological and clearly shows a common green algae characteristic. Based on the experiment results, it can conclude that the algae were similar to Dunaliella salina based on tolerances in high salinity.

\section{ACKNOWLEDGMENT}

This research was funded by Direktorat Jenderal Pendidikan Tinggi, Departemen Pendidikan Nasional according to Surat Perjanjian Pelaksanaan Penelitian Nomor: 319/SP3/PP/DP2M/II/ 2006, 1 Pebruari 2006. Greatful acknowledgment especially goes to Diponegoro University in giving chance and support in doing this research.

\section{REFFERENCES}

Ben-Amotz, A. 1993. Production of ${ }^{2}$-carotene and Vitamins by The Halotolerant Alga Dunaliella. Marine Biotechnology Vol 1. In: Attaway, D.H. \& Zaborsky, O.R. (Ed.). Pharmaceutical and Bioactive Natural Products. New York: Enum Press. 411-416p.
Bidwell, J.P. \& Spotte S. 1983. Artificial Sea Water Formulas and Methods. London: Jones \& Bartlett. 324-325p.

Borowitzka, M.A. \& Borowitzka, L.J. 1988. Limits to Growth and Carotenogenesis in Laboratory and Large-Scale Outdoor Cultures of Dunaliella salina. In Mollion, T.S et al. (Ed.) Algal Biotechnology. Kota: Elsevier. 171-180p.

Goodwin, T.W \& Britton G. 1988. Distribution and Analysis of Carotenoids. In: Goodwin T.W. (Ed.). Plant Pigments. ondon: Blackwell Sci. Pub. 75-80p.

Harborne, J.B. 1984. Metode Fitokimia. Edisi II. Bandung: Penerbit ITB. $259-261 p$.

Holt, JG., Krieg, N.R., Sneath, P.H.A., Staley, J.T. \& Williams, S.T. 1994. Bergey's Manual of Determinative Bacteriology. 9nd Ed. New York: William \& Wilkins. 377-390p.

Kusumaningrum, Soedarsono, H.P.J., Yuwono, T., \& Kusdiyantini, E. 2004. The Effect of Various Salinity Level to the Growth and Characterization of Dunaliella sp Isolated from Jepara Waters, in Laboratory Scale. ILMU KELAUTAN 9(3): 136-140.

Kusumaningrum, Soedarsono, H.P.J., Yuwono, T., \& Kusdiyantini, E. 2006. Molecular Characterization Dunaliella sp. Isolate by $18 \mathrm{~S}$ rRNA in Improvement of Carotenoid Production. Abstract. Seminar Nasional SPMIPA. Semarang, 9 September 2006. BIO 5.

Lee, P.C. \& Schmidt-Dannert, C. 2002. Metabolic engineering towards biotechnical production of carotenoids in microorganisms. Appl Microbiol Biotechnol 60: 1-11.

Lichtenthaler. 1999. The 1-Deoxy-D-Xylulose 5-Fosfate Pathway of Isoprenoid Biosynthesis in Plants. Annu. Rev. Plant Physiol. Plant. Mol. Biol. 1(50) : 47-65

Lois, L.M., Campos, N., Putra, S.R., Danielsen, K., Rohmer, M., \& Boronat, A. 1998. Kloning and Characterization of a Gene from Eschericia coli Encoding a Transketolase-like Enzymes That Catalyzes the Synthesis of 1-Deoxy-DXylulose 5-Fosfate, a Common Precursor for Isoprenoid, Thiamin and Pyridoxol Biosynthesis. Proc. Natl.Acad.Sci. 95: 2105-2110.

Rabbani, S., Beyer, P., Lintig, J.V., Hugueney, P., \& Kleinig, H. 1998. Induced 2-Carotene Synthesis Driven by Triacylglycerol Deposition in the Unicellular Alga Dunaliella bardawil. Plant Physiol. 116 (4): 1239-1248.

Sze, P. 1993. A Biology of the Algae. Third Ed. Boston: McGrawHill. 1-81p

Tomas, C. R. 1997. Identifying Marine Phytoplankton. New York: Academic Press. 858p.

Wong, V., Liu, X., \& Bidigare, R. 2000. Dependence of Carotenoid Production on Salinity in Dunaliella salina. MarBEC Summer Undergraduate Research Fellowship. Berkeley: Dept. of Oceanography, Univ. of Hawaii, Manoa \& Dept. of Biological Chemistry, Univ. of California. 1-14p. 